\title{
DIALECTS AT THE BORDER BETWEEN KOREA AND CHINA
}

\author{
Choonkyu LEE \\ University of Potsdam \\ Department of Linguistics \\ Haus 14 Karl-Liebknecht-Straße 24-25 \\ 14476 Potsdam, Germany \\ chlee@uni-potsdam.de
}

\begin{abstract}
In this paper, we seek a closer comparative dialectological study of the dialects of the Democratic People's Republic of Korea and the Korean dialects of the ethnically Korean Chinese near the Korea-China border. Accessible resources published in English and other languages besides Korean are particularly necessary in these times of increasing instability in the North Korean regime and foreseeable cases of asylum seekers. Speech samples are discussed to illustrate the relative difficulty of distinguishing between North Korean and Korean-Chinese speakers, compared to distinguishing between North Korean and South Korean speakers. Based on an overview of previous literature, some guidelines are developed for identifying some distinguishing characteristics of these speech communities. Continuing dialectological research with refugees and field research making direct comparisons between these communities are necessary for further and up-to-date insight. ${ }^{1}$
\end{abstract}

Key words: North Korea, Korean-Chinese, Korean dialects, asylum, LADO

$$
\text { 북-중 국경지역 한국어 방언 실태 }
$$

\footnotetext{
${ }^{1}$ Note on Romanization: In this paper, the Revised Romanization of Korean with assimilation is adopted for ease of reading.
} 
개략: 이 연구는 북한과, 북한-중국 국경 부근에 거주하는 한국계 중국인들의 방언 비교 분석을 다룬다. 북한 정권의 불안정과 난민의 증가가 예견되는 지금, 한국어 외에도 영어 및 다른 언어로도 볼 수 있는 자료물이 시급히 필요하다. 본고는 남-북한 방언 구분보다 북한-조선족 방언 구분이 더 힘든 점을 음성 샘플 분석을 통해 보이고, 문헌 분석을 바탕으로 이 방언들의 구분되는 특징을 찾는 데 유용한 지침을 제시한다. 지속적인 새터민들과의 협력과 비교방언학 현지조사를 통해 최신 정보를 더 구축해야 할 것이다.

키워드: 북한; 조선족; 한국어 방언; 망명; 출신지 결정을 위한 언어 분석

\section{DIALEKTY NA GRANICY KOREAŃSKO-CHIŃSKIEJ}

Abstrakt: W niniejszym artykule przedstawione zostanie badanie dialektologiczne dialektów, jakimi posługują się użytkownicy języka Demokratycznej Republiki Ludowej Korei oraz koreańskich dialektów etnicznych u Koreańczyków pochodzenia koreańsko-chińskiego na granicy koreańsko-chińskiej. Badanie tych dialektów jest obecnie niezmiernie istotne zwłaszcza w kontekście politycznym i społecznym (w zakresie osób mogących ubiegać się o azyl). Przytoczone i omówione zostają przykłady próbek mowy by zilustrować trudności w odróżnianiu osób z Korei Północnej od osób posługujących się dialektami etnicznymi koreańsko-chińskimi. Punktem wyjścia dla zobrazowania tych trudności jest uprzednie zestawienie próbek mówców północnokoreańskich i południowokoreańskich. W oparciu o dotychczasową literaturę przedmiotu, sformułowane zostają wskazówki dotyczące sposobów identyfikacji mówców należących do tych wspólnot komunikatywnych. Wskazana jest także konieczność kontynuacji badań w tym zakresie.

Slowa kluczowe: Korea Północna (KRLD), mniejszość koreańska, dialekt koreański, azyl, analiza językowa służąca ustaleniu kraju pochodzenia (LADO)

\section{Motivation}

Problems of starvation and human rights violations under the regime of the Democratic People's Republic of Korea (henceforth, North Korea) are increasingly coming to light through the media (e.g., BBC's Panorama "North Korea Undercover," Bradburn, 2013) and popular fiction and non-fiction literature (e.g., Nothing to Envy, Demick, 2009). The recent change in the leadership from Kim Jong-il to his son, Jong-un, has led to instability in the regime, as observed in 
the execution of Jang Sung-taek, Jong-un's uncle. According to the United Nations Human Rights Council (UNHRC, 2013), there are 1,321 refugees and asylum seekers originating from North Korea (as of 2013), but this is a great underestimate, due in part to refugees concealing their identities (see, e.g., the International Institute of New England, 2012). In the Republic of Korea (South Korea), the main destination for asylum seekers from North Korea, there were more than 15,000 defectors as of 2008 (National Institute of the Korean Language, 2009), and a more recent estimate states that there have been more than 26,000 defectors to the South (The Korea Herald, December 26, 2013). The South Korean media suspect there is and will continue to be a flow of defectors including top government officials (e.g., The Korea Herald, December 26, 2013).

In these sociopolitical circumstances, it is important to facilitate and improve procedures for asylum seekers originating from North Korea. Defectors, however, often lack the documentation to prove their identity and origin, because they must hide their identity during their precarious time in neighboring countries, some of which send them back to North Korea against the principle of non-refoulement. Consequently, there are several obstacles to distinguishing genuine asylum seekers from 'economic migrants' (Eades, 2005a; McNamara, 2005; Fraser, 2009). In the case of North Korea, the greatest challenge is posed by Chinese nationals of Korean descent. The majority of the roughly two million Korean-Chinese people live in Northeast China, especially Yanbian in Jilin Province, and most of them speak a North Korean dialect, with regional variation.

One procedure used in asylum cases is Language Analysis for the Determination of Origin (LADO), adopted by many governments including Australia and Sweden, and the language variation among the different North Korean dialects across the Korea-China border is critical to successful analysis, particularly in light of a recent report on false refugee claimants from Northeast China (New Focus International, August 4, 2013). While the focus of the paper is not the validity of LADO in general, it is worth pointing out the particularly difficult challenges in distinguishing between the Korean dialects on either side of the border, given the scarcity of native speakers of North Korean dialects outside North Korea, not to mention those with linguistic training. The South and North Korean dialects have diverged over the 
period of division, and South Koreans get only minimal, occasional exposure to Northern dialects through the media. Further, while there is a tradition of Korean dialectological research covering North Korean provinces and Korean-Chinese communities, much of the literature is written in Korean. There are interesting studies that deserve wider attention, including recent reports published by the National Institute of the Korean Language (NIKL) in Korean. An overview of old and new findings would be useful, especially for governments that do not work with native speakers of any Korean dialect.

\section{Introductory Description}

There are only a few accessible resources written in English on the dialects near the Korea-China border. Some English references on North Korean dialects include papers by Ross King, who has worked extensively on Korean dialects (e.g., King, 2006), particularly those of immigrant populations, as well as Sohn (2001), Yeon (2012), and Ramsey (1978) with a historical focus, particularly on South Hamgyeong.

This section provides a summary of the main characteristics of the two main North Korean dialectal regions, Hamgyeong and Pyeongan, that distinguish them from the standard South Korean dialect (see Fig. 1.), based on the linguistic descriptions in the references above, which are available in English. These two regions account for over $90 \%$ of North Korean defectors (NIKL, 2009). 


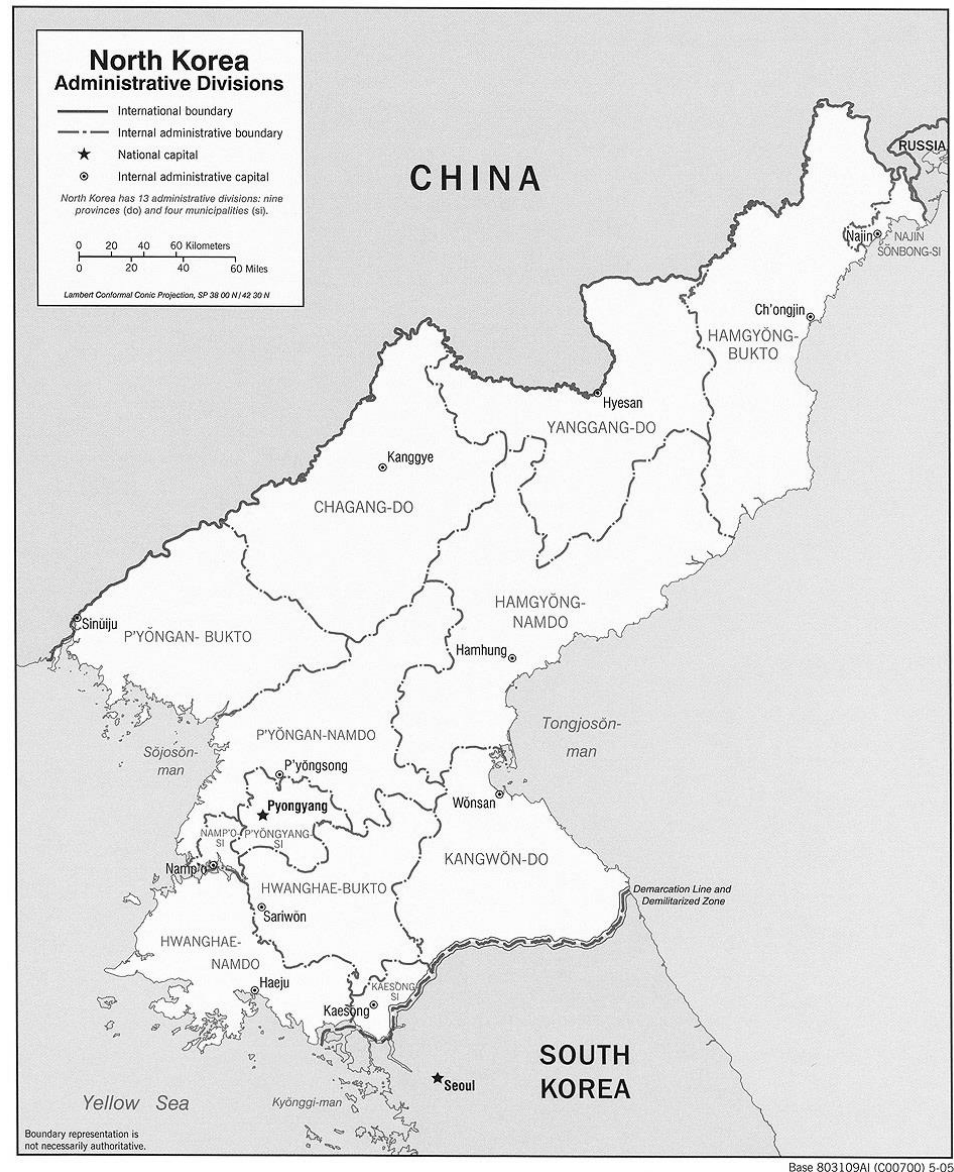

Figure 1. Administrative divisions of North Korea.

First, Hamgyeongbukdo (North Hamgyeong Province), Hamgyeongnamdo (South Hamgyeong Province), and Ryanggangdo (formerly mostly South Hamgyeong) form the Hamgyeong dialectal region, and the majority of North Korean defectors originate from this region, particularly North Hamgyeong. The 'Yukjin' area in Northeast Hamgyeong (currently the districts of Onseong, Hoeryeong, Gyeongwon, Gyeongheung, and Buryeong) shares some characteristics with the Pyeongan dialect, as discussed below.

Second, Pyeonganbukdo (North Pyeongan Province), Pyeongannamdo (South Pyeongan Province), and Jagangdo (formerly 
North Pyeongan) form the Pyeongan dialectal region. South Pyeongan surrounds the capital, Pyeongyang, and the Pyeongan dialect is often considered the 'standard' dialect (munhwaeo).

$\underline{\text { Main characteristics }}$

(examples with South Korean counterparts in parentheses)

(1) Hamgyeong

- pronunciation of Sino-Korean word-initial r [r] (also orthographically): rodong (SK nodong 'labor'); ryeoksa (SK yeoksa 'history')

- High-Low pitch accent

- palatalization of velars/glottals $/ \mathrm{k}, \mathrm{k}^{\mathrm{h}}, \mathrm{h} />\left[\mathrm{t} 6, \mathrm{t} 6^{\mathrm{h}}, \mathrm{c}\right]: / \mathrm{kil} />$ [tcil] (SK [kil] 'road')

- no palatalization of alveolars $/ \mathrm{t}^{\mathrm{h}}, \mathrm{t} />\left[\mathrm{t}^{\mathrm{h}}, \mathrm{t} \mathrm{c}\right]$ : $/ \mathrm{pat}^{\mathrm{h}} \mathrm{i} />\left[\mathrm{pet}^{\mathrm{h}} \mathrm{i}\right](\mathrm{SK}$ [pet6 ${ }^{\text {hi] }}$ 'field-NOM')

(2) Pyeongan

- pronunciation of Sino-Korean word-initial $r[c]$

- no palatalization of alveolars $/ \mathrm{t}^{\mathrm{h}}, \mathrm{t} />\left[\mathrm{t} \mathrm{c}^{\mathrm{h}}, \mathrm{t} \mathrm{t}\right]$

- pronunciation of $/ \mathrm{t} 6 /$ as dental [ [ts]

- lack of vowel rounding distinction $(/ \mathrm{N} / \mathrm{vs} . / \mathrm{o} /)$

Modern Korean in South Korea has undergone palatalization of alveolars before /i, j/, but the Pyeongan dialect and the Hamgyeong dialect in the Yukjin area are known not to have undergone this process. (In recent data (NIKL, 2009, p. 36), however, all North Korean regions seem to show this partial lack of palatalization, and the particular lexical item seems to be a bigger factor, showing wide variation from $8 \%$ to $69 \%$ overall lack of palatalization depending on the word.) These characteristics generally make the North Korean dialects very distinct from the South Korean ones, despite some similarities in pitch accent and vowel simplification between the Hamgyeong dialect and the Gyeongsang dialect in Southeast Korea. Because there is little traffic or language contact across the border between the North and the South, these characteristics help distinguish North Koreans from South Koreans quite easily.

In contrast, some characteristics are shared by the provinces of North Korea, and are probably preserved in the dialects of the KoreanChinese communities as well, making linguistic determination of origin difficult within the North, or between North Korea and North- 
east China. On the Chinese side of the border, there is a population of approximately $1,830,000$ Korean-Chinese people (2010 Chinese census), mostly in the provinces of Jilin (57\%; with most of them being of Hamgyeong descent), Heilongjiang to its north (18\%; mostly of South Korean descent, particularly Gyeongsang), and Liaoning to the southwest of Jilin (13\%; mostly of Pyeongan descent) (see Fig. 2). An early generation of migrants moved to China to seek economic opportunities, and a large group of migrants moved there for political reasons during the Japanese colonization (1910-1945).

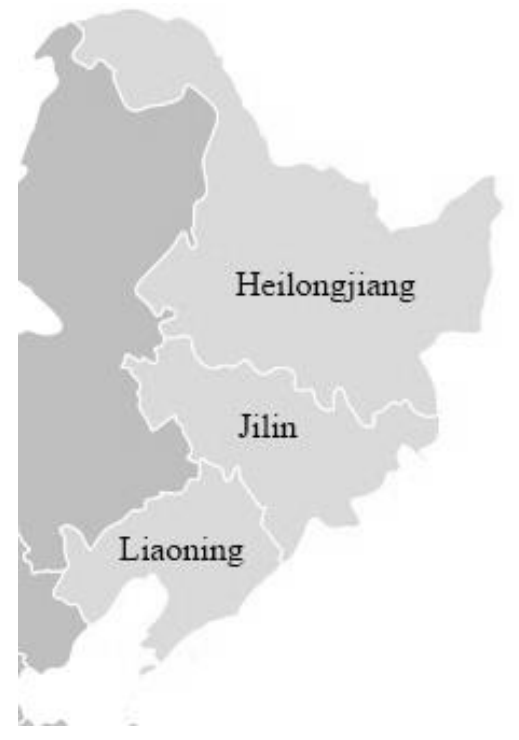

Figure 2. Provinces of Northeast China. 


\section{Recent Data on North Korean Dialects}

In 2009, the National Institute of the Korean Language (NIKL) published a preliminary report on a project for developing a language adaptation training program for North Korean defectors. This report is available online, but only in Korean. The report (NIKL, 2009) provides us with much needed information on the current dialectal situation in North Korea (albeit with a varying range of exposure to South Korean dialects), with useful statistics that allow a rough estimate of regional and individual variation. Such quantitative information was lacking in most of the earlier literature. The report contains a study of the characteristics of speech of 40 North Korean defectors, mostly from North Hamgyeong. In this sample of speakers, about $60 \%$ were from Northeast Hamgyeong surrounding Yukjin, and 27\% from Yukjin in the extreme Northeast. According to a 2008 estimate by South Korea's Ministry of Unification, nearly $70 \%$ of the new settlers in South Korea were from North Hamgyeong, and an additional 10\% from South Hamgyeong, leaving only about $20 \%$ from the other provinces.

The authors pointed out the following characteristics, some of which were discussed above:

(1) lack of rounding distinction between $/ \mathrm{N} / \mathrm{vs}$. /o/, and /u/ vs. /u/ (in $30-40 \%$ of the sample; both are phonemic distinctions in South Korean dialects)

(2) clear distinction between /e/ and / $\varepsilon /$ (in the entire sample)

(3) $n$ insertion in Sino-Korean words: geum[n]yung (SK geumyung 'finance') (60-90\%); n drop in native Korean words: /sol-nip/ > [sorip] (SK [sollip] 'pine needle,' cf. Lee, 1972) (60-100\% depending on the word)

(4) double engma instead of single engma in certain contexts

(5) lack of $/ t^{\mathrm{h}}, \mathrm{t} /$-palatalization (10-70\% depending on the word and morphosyntactic context)

(6) dropping of $/ \mathrm{w} /$ in certain diphthongs (30-50\%)

(7) non-standard consonant cluster simplification, especially for $/ \mathrm{lb} />$ [p] $($ SK [1]) (40-90\%) 
(8) free pitch accent (SK fixed stress accent) (see p. 52 for a list of patterns that diverge from the standard South Korean dialect)

(9) pronunciation of word-medial $\mathrm{r}[\mathrm{r}]$ in Sino-Korean words: na[r]yeol (SK nayeol 'arrangement'), sing[r]yang (SK sing[n]yang 'food')

\section{Korean Dialects in China}

Literature written in English on the Korean dialects of KoreanChinese communities is quite limited.

Ito and Kenstowicz (2009) studied Mandarin loanwords in Yanbian Korean. While it is not very likely that asylum seekers claiming to be from North Korea would use Chinese loanwords frequently, a close comparison between the Yanbian pronunciation of a sample of Korean words in their study and the North Korean pronunciation from other sources reveals an interesting difference:

(1)

$$
\begin{array}{ll}
\text { Yanbian: } & \text { dudeureoGI '(nettle) rash' } \\
\text { North Korean: } & \text { dudeuREOgi } \\
\text { South Korean: } & \text { duDEUreogi }
\end{array}
$$

This is also consistent with Park's (2003) claim that the rightmost accented pattern is the default pitch pattern in Yanbian Korean. It may thus be feasible to develop a vocabulary list of reliably distinctive pronunciations based on dialectological research.

Park (2003) pointed out some other important phenomena, including the phonemic borrowing of /f/ in Chinese loanwords in Yanbian Korean (the pitch accent pattern does not preserve the original Chinese tonal distinctions faithfully):

$$
\begin{array}{ll}
\text { /'fayci/ } & \text { 'house' } \\
\text { /'ph ayci/ } & \text { 'a fatty' } \\
\text { /'payci/ } & \text { 'stick' }
\end{array}
$$

The /f/ phoneme is not part of the Korean inventory, and even for highly frequent English loanwords with the phoneme /f/, South Koreans typically use /ph/. (Being accurate with the /f/ pronunciation in loanwords may even seem as if one is showing off her/his English 
skills.) Another phenomenon is (incorrect) hypercorrection of the default Yanbian pitch accent pattern for loanwords from South Korean, with stress on the first syllable. In other words, even for South Korean words that have stress on the final syllable (e.g., insaeng 'life,' yeohaeng 'travel,' musik 'ignorant'), Yanbian speakers sometimes produce the predominant first-syllable stress pattern of standard South Korean to replace their rightmost pitch accent pattern. These hypercorrections may be another point of divergence between the KoreanChinese and North Koreans.

The NIKL published a report (NIKL, 2012) based on a survey of the three Chinese provinces above and Qingdao, with a new community of Korean-Chinese people, regarding their language use and metalinguistic attitudes. This report is available only in Korean, but is important for comparison between the dialects across the Korea-China border. The authors described a rapidly increasing influence of the Chinese language and pressure toward linguistic integration in these communities. The report includes lists of direct loanwords from Mandarin (typically a Northeastern dialect) into their Korean dialect and novel Sino-Korean words replacing those in North Korean dialects (e.g., gwangjangmu 'public dance'; NIKL, 2012, pp. 227-228).

Some of the most frequent words, such as kinship terms (NIKL, 2012, Section 5.2.2.), may not be easy to correct deliberately in rapid conversation, and thus deserve particular attention. Note some forms that differ from the standard South Korean form (although these are only some among many alternative forms):

'mother' (SK eomeoni)

Jilin, Heilongjiang: eomani, eomeoi

Liaoning, Qingdao: mama (cf. NK: (e)omani, eomeoi, eomai)

'father' (SK abeoji)

Jilin, Heilongjiang: abuji

Liaoning, Qingdao: ppa, ppappa

(cf. NK: abaji, abuji) 'grandfather' (SK harabeoji) Jilin, Heilongjiang: aba(n)i, halbae, harabuji Liaoning, Qingdao: halbae, abai, keunabae (cf. NK: keurabani, abani) 


\author{
'grandmother' (SK halmeoni) \\ Jilin, Heilongjiang: amae, halmae, halmai, halmeoi \\ Liaoning, Qingdao: halmae, halmeoi, amae \\ (cf. NK: keulmani, amae)
}

We see more diverging patterns between North Korea and China, e.g., halbae in (5) and halmae in (6), which are used by Korean-Chinese people of Gyeongsang (Southeast Korean) descent, and thus much less likely in North Korean speech.

According to Park (2003), the close political alliance between China and North Korea in the 1960s-70s led the Chinese premier at the time, Zhou Enlai, to promote explicitly the standard North Korean dialect of Pyeongyang (located within South Pyeongan) for Yanbian rather than the standard South Korean dialect, but due to the predominantly Hamgyeong roots of the Korean-Chinese in the region, the official language policy does not seem to have had much impact on everyday language use. After the economic reform of China and the ensuing influx of South Korean businesses and culture, many Yanbian TV journalists and entertainers have adopted a South Korean accent by now. The Yanbian TV programs, some of which are easily accessible, are thus not the best resources for studying the Yanbian Korean dialect unfortunately.

\title{
5. Speech Samples
}

In this section, we explore to what extent the known North Korean dialectal features and lexical items documented in previous literature appear in recently recorded speech samples of Korean speakers. These recordings were obtained from an immigration service in Europe, and were made for the purpose of LADO. I analyzed speech samples from anonymous speakers claiming to be from various regions of North Korea, and the data illustrate some of the characteristics discussed above. For simplicity, we disregard age, gender, and family origins in this discussion. Each sample was approximately 15 minutes long in net duration, and each speaker spoke about their origin and back- 
ground. For this paper, we have selected 22 speech samples in which the claimed origin from a Northern province was very likely to be true, based on both the accent and their local knowledge. Note that, strictly speaking, the true origin of these speakers is unknown, and thus one should not draw any conclusions from these recordings. Our aim is to provide an indication of which features documented in the literature would appear to be particularly helpful in the linguistic analysis of speech samples in the context of an asylum procedure.

The following section describes linguistic features within two groups of speakers: those who claim to come from Hamgyeong and Ryanggang (Northeast), and those who claim to come from Pyeongan and Pyeongyang (Northwest). As will be discussed below, it is certainly feasible on the basis of established linguistic features to distinguish speakers of Northern dialects from South Koreans, but it is extremely difficult to distinguish between North Koreans and the Korean-Chinese or estimate their length of possible stay in China and/or South Korea without further knowledge of the dialectal differences across the Korea-China border. ${ }^{2}$

\subsection{Claimed Origin: (a) Hamgyeong and Ryanggang (for- merly mostly Hamgyeong $)^{3}$}

\section{Phonology}

(1) dropping of $/ \mathrm{n} /$ before $/ \mathrm{i} /$ :

Interviewees \# 1, 6 [mei] (SK [meni] 'much'); \#5, 6 [helmei] (SK [helmıni] 'grandmother');

\footnotetext{
${ }^{2}$ Due to the brevity of the samples, however, it is important to note that not being listed for a feature in this section does not necessarily imply a lack of the relevant feature in the speaker.

${ }^{3}$ Claimed origin of the interviewees: \#1, 2 Hoeryeong; \#3, 4 Gyeongwon/Onseong; \#5 Hyesan; \#6 Hwaseong/Cheongjin; \#7 Hoeryeong; \#8 Cheongjin; \#9 Huchang/Dancheon; \#10, 11 Riwon; \#12 Cheongjin; \#13 Hoeryeong; \#14 Huchang; \#15 Onseong; \#16 Yeonsa; \#17 Cheongjin; \#18 Onseong.
} 
\#6, 18 [ei] (SK [eni] 'not'); \#17 [edzumei] (SK [edzumıni] 'ma'am')

(2) dropping of $/ \mathrm{w} /$ in certain diphthongs:

\#1 [herj $\wedge$ ]] (SK [hwerjıy] 'Hoeryeong');

\#2 [hengj $\Lambda$ ]] (SK [hwengj $\wedge$ ]] 'environment/condition');

\#7 [hengep] (SK [hwengep] '60th birthday');

\#11 [helssk] (SKK [hwels $\Lambda$ k] 'talcum');

\#13, 17 [hehek] (SK [hwehek] 'chemistry'

(3) pronunciation of Sino-Korean word-initial r [r]:

\#3, 4, 14, 16 rodong (SK nodong 'labor');

\#3 ryeohaeng (SK yeohaeng 'travel');

\#5 rokhagi (SK nokhwagi 'recorder');

\#6 roksaek (SK noksaek 'green');

\#7, 11 ronggu (SK nonggu 'basketball');

\#10, 15 rihae (SK ihae 'understanding');

$\# 11$ riik (SK iik 'benefit');

\#13, 16 ryeoksa (SK yeoksa 'history');

\#16 rimsan (SK sallim/imsan 'forestry')

(4) lack of palatalization of alveolars:

\#4 kkeu[ $\left.\mathrm{t}^{\mathrm{h}}\right]$ imnida (SK kkeu[t $\left.6^{\mathrm{h}}\right]$ imnida 'That's it./This is the end.');

$\# 10 \mathrm{kkeu}\left[\mathrm{t}^{\mathrm{h}}\right]$ igo (SK kkeu[t $\left.6^{\mathrm{h}}\right]$ igo 'it is the end, and [...]');

$\# 5,18 \mathrm{ba}\left[\mathrm{t}^{\mathrm{h}}\right] \mathrm{i}$ (SK ba[t $\left.6^{\mathrm{h}}\right] \mathrm{i}$ 'the field (nominative case)');

\#12 ba[t $\left.\mathrm{t}^{\mathrm{h}}\right]$ imnida ( $\mathrm{SK}$ ba[ $\left[\mathrm{t}^{\mathrm{h}}\right]$ imnida 'it is farmland')

(5) palatalization of velars:

\#10 ga[t $\left.\mathrm{t}^{\mathrm{h}}\right]$ aunikka (SK ga[k]aunikka 'because it is close')

(6) non-standard assimilation/consonant cluster simplification:

\#10: sinseonno (SK sinseollo 'hot pot');

\#12 yeodeopssal (SK yeodeolssal '8 years of age')

(7) pronunciation of $/ \mathrm{N} /$ as [o], and $/ \mathrm{w} / \mathrm{as}[\mathrm{u}]$ :

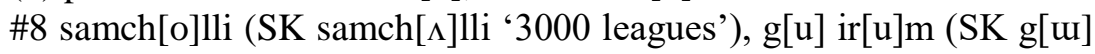
ir[u]m 'that name');

\#18 h[o]mu (SK h[ $\Lambda$ ]mu 'futility)

(8) \#10 ttakkatta (SK tokkatta 'they're the same'), geojin (SK geoeui 'almost')

(9) tense pronunciation: \#4 gagi [ [ts]eone (SK gagi [tc]eone 'before going'), \#18 [6] ]ibiwol (SK [6]ibiwol 'December')

It is important to keep in mind that Speakers \#1, 2, 3, 4, 7, 13, 15 , and 18 claim to be from the 'Yukjin' area; further, \#9 and \#14 are purportedly from Huchang (currently 'Kim Hyong-jik County'), a 
region in Ryanggang Province bordering Pyeongan, even though King (2006) grouped it together with Hamgyeong linguistically. No distinct patterns emerge between these subgroups (besides the VP particle -ri below for Speakers \#1, 3, and 18 purportedly from the Yukjin area; see Morphosyntax).

\section{Morphosyntax}

(1) characteristic sentence-enders:

\#1 eodi gamdu 'where are you going?';

\#3 meoraemdu 'what is (s)he saying?';

\#6 jyaeneun eodiseo wasseumme 'where is that person from?';

\#7 ige eolmamdu 'how much is this?';

\#16 eodi gatta omdung 'where have you been?';

\#17 mohamdu 'what are you doing?'

(2) negation:

\#6 deureo mot bwasseumnida (SK mot deureo bwasseumnida / deureoboji mot haesseumnida 'I haven't heard'), mideo ai jineungemnida (SK an mideojineungeomnida / mideojiji an(h)neungeomnida 'I couldn't believe it');

\#12 ara mot deudeoyo (SK mot aradeureoyo 'One can't understand')

(3) relative clause:

\#8 algeon deneun (SK aneun geoseun 'as far as I know, in my knowledge')

(4) VP particle -ri:

\#1, 18 joreophamyeonseori 'after graduating,' naeryeoomyeonseori 'as one comes down', \#3 haegamyeonseori 'while doing'

The non-standard position of the negation particle within the VP seems unique to the Hamgyeong dialect (King, 2006), and has not been observed in Pyeongan speech.

Lexicon

(\#3) oksikki (SK oksusu 'corn'), doti (SK dwaeji 'pig')

(\#4) deodeolgi (SK deodeok 'mountain herb, Codonopsis lanceolata'), rorak (SK byeo 'rice')

(\#4, 6) bense (SK mandu 'dumpling')

(\#5) gugangwon (SK chigwa 'dental clinic'), geuruppa (from Russian gruppa; SK geurup 'group')

(\#6) gasae (SK gawi 'scissors')

$(\# 6,18)$ noreum (SK nori 'game') 
(\#7) roim (SK imgeum 'wage, pay'), buseukkae (SK agungi 'furnace'), sakari (SK seoltang 'sugar')

(\#7, 12) ipssal (SK ssal 'rice')

(\#8) siksujeol (SK sikmogil 'arbor day')

(\#8, 13, 15) jangmadang (SK sijang 'market')

(\#9, 18) nyum (SK alluminyum 'aluminum')

(\#11) bbangtong (SK hwamulkan 'train car')

(\#12) jjaepo (SK jaeil gyopo 'Korean Japanese (sent to North Korea)')

$(\# 12,15)$ gangnaengi, gangnae (SK oksusu 'corn')

(\#14) rajio (from Japanese; SK radio 'radio')

(\#16, 17) mongrankkot (SK moran(kkot) 'peony'), gyowon (SK gyosa 'teacher'), amae (SK halmeoni 'grandmother'), abai (SK harabeoji 'grandfather')

(\#17) tteurakttoreu (from Russian traktor; SK teuraekteo 'tractor'), jabatteugae (SK sujebi 'dumpling soup'), detteurong (SK tetoron 'Tetoron'), dundeok (SK eondeok 'hill'), bbanjjakjji 'bright fabric'

(\#18) gojo (dummy filler)

These numerous examples demonstrate that distinguishing a North Korean dialect from standard South Korean should not be difficult, but pinpointing the exact area of a speaker's origin near the Korea-China border remains a challenge, especially due to some language contact in the area among merchants. For example, Speaker \#3 used the word georeumai 'pocket,' which, according to the NIKL dictionary (http://www.korean.go.kr/09_new/dic/local/word_local.jsp), has been documented in an area of Yanbian not far from the border city that the speaker claims to come from. Another word, jeopgan 'hospitality' (from Speaker \#4), has not been documented in any known references. 


\subsection{Claimed Origin: (b) Pyeongan and Pyeongyang ${ }^{4}$}

\section{Phonology}

(1) pronunciation of $/ \mathrm{N} /$ as $/ \mathrm{o} /$ :

Interviewee \#19 nawas[o] (SK nawas[ $\Lambda$ ] 'after getting out');

\#20 s[o]ngch[o]ngun $\mathrm{d}[\mathrm{o}] \mathrm{kch}[\mathrm{o}] \mathrm{nsi} \quad(\mathrm{SK} \quad \mathrm{s}[\Lambda] \mathrm{ngch}[\Lambda]$ ngun $\mathrm{d}[\Lambda] \mathrm{kch}[\Lambda] \mathrm{nsi}$ 'Seongcheon-gun (district) Deokcheon-si (city)');

\#22 g[o]ns[o]l (SK g[ $\Lambda] \mathrm{ns}[\Lambda] 1$ 'construction'), $\mathrm{tt}[\mathrm{o}] \mathrm{k}$ (SK tt[ $[\Lambda] \mathrm{k}$ 'rice cake'), bob (SK beob 'law')

(2) dropping of $/ w /$ in certain diphthongs:

\#21 [hey tcey j $\Lambda$ ] ] (SK [hwey tcen j $\wedge$ ] ' Hwang Jang-yop')

(3) pronunciation of Sino-Korean word-initial r [r]:

\#21 [r]yeonseup (SK yeonseup 'practice')

(4) lack of palatalization of alveolars:

\#22 [t ${ }^{\mathrm{h}}$ ii] (SK [t $6^{\mathrm{h}}$ ii] 'difference')

Lexicon

(\#19, 22) gangnaengi (SK oksusu 'corn')

(\#20) wenggeuria (SK heonggari 'Hungary'), gaejjak (SK sangja 'box'), roim (SK imgeum 'wage')

(\#22) gojo (dummy filler); namsae (SK namul '(wild) vegetable'), reryu (from Japanese reru; SK reil 'rail')

While the dialectal characteristics of this region that differ from standard South Korean are not as numerous, it is nevertheless not difficult to detect these unique phonological characteristics and lexical items above even within a brief speech sample. The greater challenge again is to tell true defectors from this region apart from KoreanChinese individuals.

\footnotetext{
${ }^{4}$ Claimed origin of the interviewees: \#19 Pyeongyang; \#20 Bukchang; \#21 Ryongcheon/Pyeongyang/Suncheon; \#22 Pyeongyang.
} 


\subsection{Lexicon Specific to North Korea}

The following are some lexical items from the speech samples that apply specifically to the North Korean sociopolitical system:

bowibu 'state political security department'

anjeonbu 'ministry of public security'

inminban 'people's group'

gongmu dongryeok jikjang 'equipment maintenance (department)'

hamonika jib/sataek 'houses built close together; harmonica house'

rogan 'labor management'

bunjo(jang) 'group (leader)'

gukdon '(North Korean) currency'

bunjuso (SK pachulso 'security office')

godeungjunghakgyo (SK junghakgyo 'middle school,' godeunghakgyo 'high school')

gongminjeung (SK jumindeungnokjeung 'ID')

There has also been a multi-year project for creating a comprehensive comparative North-South Korean dictionary by scholars from both South and North Korea (http://www.gyeoremal.or.kr/ eng/jsp/index.jsp).

\subsection{Discussion and Guidelines for Analysis}

These numerous phonological and lexical examples demonstrate that, despite the mutual intelligibility between the North and South Korean dialects, they are quite distinct (see also Yang, 2013). Due to the unique sociopolitical circumstances on the Korean peninsula with a long history of division with minimal language contact across the North-South border, it is relatively easy to distinguish a Northern dialect from a Southern one. In contrast, it is much more difficult to distinguish a North Korean from a Korean-Chinese based on currently available knowledge because of the North Korean ances- 
try of the majority of the Korean-Chinese (except for those from Heilongjiang).

In these speech samples, eliciting the most typical characteristics of their dialect in pretend situations of casual conversation usually led to the production of the dialect-specific sentence-enders. Eliciting typical sentence-enders of the speaker's dialect thus may be a useful procedure for learning more about the person's origin. Having speakers imagine different levels of politeness contexts (e.g., speaking to a younger friend, an older friend, one's grandparent, a friend's parent, etc.) may also be useful in eliciting dialect-specific markers of politeness, which is a prominent aspect of Korean.

Other socio-/metalinguistic aspects of speech are sometimes strong signs of the speaker's origin: For example, the terms the speaker uses to refer to his/her own people, language, country, and political leader may give us clues to his/her recent experiences and how much time (s)he spent outside the country of origin. After a lifetime under an oppressive regime in which informing on reactionaries is encouraged, it would take more than just a few months in hiding to switch completely to a consistently third-party (non-North Korean) system of language habits and word choice due to the particular sociopolitical context, although one should be aware of possible counteracting factors, such as communication accommodation (to a South Korean interpreter or a foreign government official) (cf. Giles, Coupland and Coupland, 1991). In addition, with regard to the intensive training reported in the media (New Focus International, August 4, 2013) for the Korean-Chinese preparing to apply for asylum as North Koreans, these metalinguistic aspects are probably more malleable and easier to modify at the level of conscious awareness than subtle articulatory or morphosyntactic differences.

Further, for governments and agencies that practice LADO, it is critical that a linguistic expert and a trained native speaker collaborate in real time in writing up the final version of the analysis report. LADO reports that I have seen sometimes contain incorrect descriptions of the target language which even an untrained native speaker would detect easily. Such reports appear to have been prepared initially with a native speaker's observations, and subsequently revised by a non-native linguist single-handedly for the final draft, just based on reference grammars without direct consultation again with a native 
speaker. In order to combine their valuable expertise, linguists and native speakers should work in tandem on each case (cf. CambierLangeveld, 2012) and finalize the report together at the very least. While it is true that relying too heavily on native speakers without proper linguistic training is undesirable for purposes of LADO (Fraser, 2009), the same is true for relying just on professional linguists without a native speaker's knowledge of the language.

In the case of asylum seekers claiming to be from North Korea, it may be practically impossible to find all the required expertise combined in one person, namely, a native speaker from the claimed area of origin (North Korea) with sufficient linguistic-dialectal training, or a near-native specialized linguist with extensive firsthand experience in the North Korean dialects. There are two broad alternatives for finding adequate consultants: (1) to provide a native speaker of a North Korean dialect with the necessary linguistic training for the purposes of LADO, or (2) to provide a linguistically trained native speaker of a South Korean dialect with the necessary dialectal training for recognizing characteristics of a North Korean dialect, along with training materials such as speech samples with a confirmed origin. In both cases, specialized training by a 'supervising linguist' is necessary (Cambier-Langeveld, 2012). For the latter option, which is more feasible, further efforts are needed in developing accessible resources for learning the differences between the dialects of South Korea, North Korea, and the Korean communities in China. In the case of South Korea, such efforts would prove useful for organizations such as the Ministry of Unification and the National Intelligence Service.

\section{Concluding Remarks}

Obtaining refugee status can be a matter of life and death for asylum seekers, especially North Korean defectors, who would be considered political prisoners if sent back. Anyone who contributes to the decision-making process in asylum cases must take each procedure seriously and do their utmost to improve its accuracy. In the case of North 
Korea, there are two things linguists can do and should do urgently: (1) to make the existing knowledge more accessible, but with due caution at the same time against potential abuse; and (2) to conduct further dialectal research to compare the variants across the KoreaChina border. There are valuable resources on either North Korean dialects or Korean-Chinese dialects, but resources directly comparing the two regions are scarce, and the information on dialectal variation must continue to be updated.

Continuing field research around the border areas would provide the most accurate insight, but due to practical restrictions with North Korea, it would be best to collaborate with recent refugees whose origin has been confirmed with a high degree of certainty. Recent studies, especially from the NIKL, with quantitative measures of regional and individual variation among North Koreans and KoreanChinese individuals contribute critical information; however, as the findings have only been published in Korean, it is important to share the knowledge in other languages for language experts and language analysis practitioners around the world.

Besides distinguishing Korean-Chinese applicants from North Korean defectors, there is also the issue of preventing abuse of asylum by 'asylum shoppers,' who, after obtaining refugee status in one country, apply later for asylum in yet another country. The full extent of legal considerations is beyond the scope of this paper, but nevertheless an important issue for national governments to settle.

\section{References}

Bradburn, Howard. 2013. North Korea undercover. BBC. April 19. Cambier-Langeveld, Tina. 2010. The validity of language analysis in the Netherlands. In Language and origin: The role of language in European asylum procedures: Linguistic and legal perspectives, ed. Karin Zwaan, Maaike Verrips and Pieter Muysken, 21-34. Nijmegen: Wolf Legal Publishers. 
Demick, Barbara. 2009. Nothing to envy: Ordinary lives in North Korea. New York: Spiegel and Grau.

Eades, Diana. 2005. Applied linguistics and language analysis in asylum seeker cases. Applied Linguistics, 26(4), 503-526.

Fraser, Helen. 2009. The role of 'educated native speakers' in providing language analysis for the determination of the origin of asylum seekers. International Journal of Speech Language and the Law, 16:113-138.

Giles, Howard, Justine Coupland and Nikolas Coupland. 1991/2010. Contexts of accommodation: Developments in applied sociolinguistics. England: Cambridge University Press.

International Institute of New England. 2011. Background on North Korean refugees. http://iine.us/2011/12/background-on-northkorean-refugees/ (accessed August 28, 2015).

Ito, Chiyuki and Michael Kenstowicz. 2009. Mandarin loanwords in Yanbian Korean II: Tones. Language Research, 45(1), 85-109.

King, Ross. 2006. Dialectal variation in Korean. In Language in Korean Culture and Society, ed. Ho-Min Sohn, 264-280. Honolulu: University of Hawaii Press.

Lee, Chungmin. 1972. Boundary phenomena in Korean revisited. Research on Language \& Social Interaction, 5(3), 454-474.

McNamara, Tim. 2005. 21st century shibboleth: Language tests, identity and intergroup conflict. Language Policy, 4, 351-370.

New Focus International. August 4, 2013. False North Korean asylum claimants use bought photographs as supporting evidence. http://newfocusintl.com/north-korean-asylum-claimants/ (accessed August 28, 2015).

Park, Youngmae. 2003. A preliminary study of the language of ethnic Koreans in China: Toward a sociolinguistic understanding. Kyoto University Linguistic Research, 22: 1-21.

Ramsey, Samuel Robert. 1978. Accent and morphology in Korean dialects. Seoul: Tab Chulpansa.

Sohn, Ho-Min. 2001. The Korean language. Cambridge, UK: Cambridge University Press.

The Korea Herald. December 26, 2013. N. Korea struggles to stem flow of defectors after bloody purge. http://www.koreaherald.com/view.php?ud=20131226000501 (accessed August 28, 2015). 
The National Institute of the Korean Language. 2009. Development of a language adaptation training program for new settlers (Saeteomin eoneo jeogeung hunryeon program gaebal yeongu). http://www.korean.go.kr/front/reportData/reportDataView.do?re port_seq $=456 \& m n \_i d=45$ (accessed August 28, 2015).

The National Institute of the Korean Language. 2012. The actual state of the language of Korean-Chinese (Jaejung dongpo eoneo siltae josa). http://www.korean.go.kr/front/reportData/reportDataView.do?report_seq=653\&mn_id=45 (accessed August 28, 2015).

United Nations Human Rights Council. 2013. 2013 UNHCR regional operations profile - East Asia and the Pacific: Democratic People's Republic of Korea. http://www.unhcr.org/pages/49e488f56.html (accessed August 28, 2015).

Yang, Sookyung. 2013. Language accommodation of North Korean refugees (Bukhan italjumineui eoneo jeogeung siltaeeui gwanhan yeongu). Doctoral dissertation, Seoul National University.

Yeon, Jaehoon. 2012. Korean dialects: A general survey. In The languages of Japan and Korea, ed. Nicholas Tranter, 168-185. Abingdon and New York: Routledge. 